\title{
THE EFFECT OF WASTE FROM MINERAL WOOL MANUFACTURING ON THE PROPERTIES OF CONCRETE
}

\author{
\#DŽIGITA NAGROCKIENE், EDVINAS POCIUS, INGRIDA GIRNIENE்
}

Vilnius Gediminas Technical University, Sauletekio av. 11, Vilnius, LT-10223, Lithuania

\#E-mail: dzigita.nagrockiene@vilniustech.lt

Submitted January 25, 2021; accepted February 20, 2021

\begin{abstract}
Keywords: Waste from mineral wool manufacturing, Concrete, Compressive strength, Frost resistance
The article analyses the effect of the residues from mineral wool manufacturing (mineral dust) on the properties of concrete. Concrete mixes were made of cement, sand, gravel, superplasticiser, water and mineral dust generated as a residue stream in the manufacture of stone wool. Different compositions of concrete mix were designed where cement was replaced by mineral dust at $0 \%, 2.5 \%, 5 \%$, and $7.5 \%$ by weight of cement. Tests were made to determine the following characteristics of concrete modified with different amounts of mineral dust: density, compressive strength, ultrasonic pulse velocity, water absorption rate, resistance to cyclic freeze-thaw action. The evaluation of physical and mechanical properties of the tested concrete revealed that modification of concrete with $5 \%$ of mineral dust leads to higher density, ultrasonic pulse velocity, compressive strength and resistance to cyclic freezing and thawing and lower water absorption rate. Concrete modified with up to $5 \%$ of mineral dust by weight of cement in the mix is durable concrete that can be used in engineering structures.
\end{abstract}

\section{INTRODUCTION}

Lowering the amount of cement in concrete mix is one of the main goals in concrete industry. Cement manufacture has a negative environmental impact due to big amounts of natural resources used and high levels of $\mathrm{CO}_{2}$ emission [1]. The cement industry is the second biggest contributor of greenhouse gas in the world responsible for approx. 5 - $8 \%$ of the global $\mathrm{CO}_{2}$ emission [2]. Using cement replacement materials, such as slag of fly ash, is a common practice in concrete industry [3].

The production process for stone wool generates a number of residue streams. The total amount of waste generated in the 26 stone wool plants operating in the EU is estimated to be between 160000 and 80000 tonnes per year, representing a substantial $20-60 \%$ of total output [4]. This waste takes a lot of storing space and, if stored in the open areas, it pollutes groundwater, soil, plants and the atmosphere. Burying stone wool process waste in conventional landfills is forbidden by environmental regulations [5-7]. Mineral wool producers have to pay landfill disposal fees. Companies are interested in reducing the production costs by recycling stone wool production process waste. Conversion of such waste into construction materials is one of the recycling techniques [5, 8- 9].

Three residue streams are generated in stone wool manufacturing: mineral wool fibres, melted nonfiberised shots, and mineral dust. The first two types of residue can be returned to the production process along with the input of raw materials after pressing or briquetting the waste with the use of binders [10-13]. The third type of residue generated in stone wool manufacturing is mineral dust. About $20 \mathrm{~kg} \cdot \mathrm{h}^{-1}$ of fine particles from the melting feed are exhausted with the fume. The dust is deposited in sleeve filters. From the filters it is transported to the combustion chamber where $\mathrm{CO}$ and fine particles of the feed are burned to minimise the environmental impact [14].

Authors describe that mineral dust, which is exhausted from cupola furnaces and deposited in the filters in other industries (e.g. metal industry), is composed of amorphous $\mathrm{SiO}_{2}$ and can be successfully utilised in the manufacture of construction materials [15-16].

Researchers have also found that this dust is mainly composed of two minerals: halite and sylvite. The addition of mineral dust generated in stone wool manufacturing into cement was found to improve its initial hydration, promote the formation of Friedel salts in Portland cement mix and reduce the compressive strength. The compressive strength is increased after washing out the chlorides from stone wool dust. The addition of mineral wool production process residues into cement-based products increases their compressive strength, tensile strength, and wear resistance, improves absorption properties and alkali resistance [5, 14].

Mineral dust from stone wool production process is used as an addition in refractory concrete manufacturing. Mineral dust is used to replace silica dioxide. $800^{\circ} \mathrm{C}$ was found to be the optimal temperature for the application of concrete modified with stone wool dust. At this temperature the physical and mechanical properties 
as well as resistance to thermal shock of mineral dust modified concrete had little difference compared to concrete compositions containing silica dioxide. The recommended mineral dust content in concrete compositions shall not exceed $2 \%$ [11].

Mineral dust from stone wool production process is a semi-crystal material containing mainly silica dioxide and soluble alkali. The shape of stone wool dust particles changed from the round shape to needle shape at $800{ }^{\circ} \mathrm{C}$ temperature. A certain part of amorphous compounds acquired the crystalline structure thus forming aluminium silicate complexes and edenite [11].

Mineral dust from stone wool production process can be used to replace different types of cement in the manufacture of concrete. The authors used the following three types of cement for the tests: CEM I R, CEM I $\mathrm{N}$, and CEM II/A-S. Mineral dust was found to reduce the slump of cement paste but did not have a significant effect on the early compressive strength of concrete; however, the increase in compressive strength slowed down in the specimens made of cement CEM I R and CEM I N, whereas in the specimen made of cement CEM II/A-S the compressive strength increased faster. This effect on the development of compressive strength was caused by alkaline substances present in the mineral dust. Authors concluded that mixing mineral dust with slag cement would be the best practice to utilise the stone wool production process residue [17].

Researchers have been investigating alkali activated slag geopolymerns, which usually contain sodium or potassium alkali and active pozzolans. Van Deventer together with other researchers have proved that $\mathrm{Si}-\mathrm{Al}$ materials, such as fly ash, bottom ash, silica fume, some natural minerals, mine tailings, kaolin, construction waste can be utilised in the production of geopolymers [8].

Stone wool production process residue was used to produce lightweight geopolymers. Researchers used sodium alkali as an activator, ground stone wool production residue, fine aggregate, gasifier (aluminium powder), and cellulose as water retaining agent. The geopolymer foam concrete containing stone wool production residue had the density values ranging between 610 and $1130 \mathrm{~kg} \cdot \mathrm{m}^{-3}$, compressive strength values from 1,7 to 5.4 $\mathrm{MPa}$ and heat transfer coefficient values from 0,144 to $0.345 \mathrm{~W} \cdot \mathrm{m}^{-1} \cdot{ }^{\circ} \mathrm{C}^{-1}$. Researchers concluded that the application of stone wool production residue may lead to significant reduction of expensive materials used to produce geopolymers: the amount of sodium alkali can be reduced more than twice and the amount of aluminium powder can be reduced more than $10 \%[18]$.
Researchers who investigated alkali activated slag binders also worked with stone wool production residue. They studied composites of different compositions and their ability to withstand the corrosion caused by the biological environment. The study resulted in the development of a new building material containing mineral wool production residue with improved physical, mechanical and performance properties. The specimens containing ground waste with the grinding fineness of $400-450 \mathrm{~m}^{2} \cdot \mathrm{kg}^{-1}$ had the compressive strength of $68 \mathrm{MPa}$. Researchers also found that such material may be used in buildings and structures where aggressive biological environments can occur [19].

The use of cement substitutes in the production of concrete reduces the amount of cement used, which in turn reduces carbon dioxide emissions. Cement can be also substituted by residues and by-products from other industries. Stone wool production process residue is one of those cement substitute materials. Mineral dust generated in stone wool production process has not been sufficiently investigated and has not been applied in the production of concrete yet. The purpose of this study is to investigate the effect of mineral wool production residue on the mechanical and physical properties of concrete and to evaluate the application of this addition in the production of concrete.

The conducted tests revealed that the optimal content of mineral dust used to replace cement is up to $5 \%$ because the strength and physical properties of concrete improve compared to control specimens.

\section{EXPERIMENTAL}

Cement CEM I $42.5 \mathrm{R}$ complying with the requirements of LST EN 197-1 [20] and mineral dust generated in stone wool production process were used in the tests. Physical properties of mineral dust are presented in Table 1. Chemical composition of the dust is presented in Table 2. Table 3 presents the properties of sand, fraction $0 / 4$, and gravel, fraction $4 / 16$, used in the concrete mix and they meet the properties under LST EN LST EN 12620:2003+A1:2008 [21].

Table 1. Properties of mineral dust.

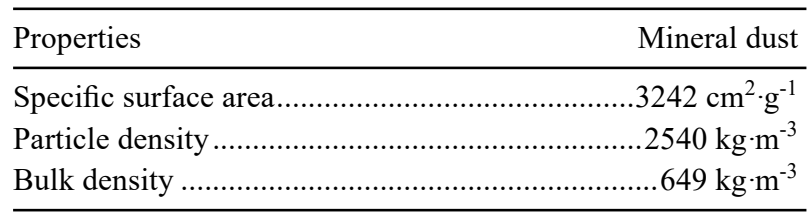

Table 2. Chemical composition of mineral dust.

\begin{tabular}{ccccccccccc}
\hline \multicolumn{10}{c}{ Chemical composition of mineral dust (\%) } \\
\hline $\mathrm{SiO}_{2}$ & $\mathrm{CaO}$ & $\mathrm{Cl}$ & $\mathrm{K}_{2} \mathrm{O}$ & $\mathrm{Fe}_{2} \mathrm{O}_{3}$ & $\mathrm{Al}_{2} \mathrm{O}_{3}$ & $\mathrm{MgO}$ & $\mathrm{Na}_{2} \mathrm{O}$ & $\mathrm{SO}_{3}$ & $\mathrm{ZnO}$ & Other \\
\hline 21.5 & 14.7 & 10.6 & 7.80 & 5.53 & 5.12 & 5.07 & 4.87 & 4.18 & 2.13 & 18.5 \\
\hline
\end{tabular}


Table 3. Properties of aggregates.

\begin{tabular}{lcc}
\hline Properties & Sand & Gravel \\
\hline Particle size distribution & $0 / 4$ & $4 / 16$ \\
Particle density $\left(\mathrm{kg} \cdot \mathrm{m}^{-3}\right)$ & 2650 & 2600 \\
Bulk density $\left(\mathrm{kg} \cdot \mathrm{m}^{-3}\right)$ & 1670 & 1580 \\
Water absorption $(\mathrm{wt} . \%)$ & $\leq 1.0$ & $\leq 2.0$ \\
(after 24 h of soaking) & $\leq 0.01$ & $\leq 0.01$ \\
Water - soluble chlorides (\%) &
\end{tabular}

The dry method was used to determine the specific surface area and particle size distribution of mineral dust by means of particle size analyser Cilas 1090 LD in the interval from $0.01 \mu \mathrm{m}$ to $500 \mu \mathrm{m}$ using air as a carrier. The particles were dispersed by ultrasound until $12 \%$ distribution of the material in the media was reached. The measuring span was $15 \mathrm{sec}$. Standard operating system Fraunhöfer was used.

The test results showed that particle size was $15 \mu \mathrm{m}$. $90 \%$ of the particles were smaller than $216.55 \mu \mathrm{m}, 50 \%$ of the particles were smaller than $1385 \mu \mathrm{m}$ and $10 \%$ of the particles were smaller than $1.36 \mu \mathrm{m}$. Mineral dust particle size distribution is shown in Figure 1.

Concrete specimens were prepared according to LST EN 12390-2 [22]. Compositions of concrete mix are presented in Table 4. Specimens were made from concrete mix were a certain portion of cement was replaced by mineral dust. A constant water/cement ratio of 0.55 was maintained in all mixes.

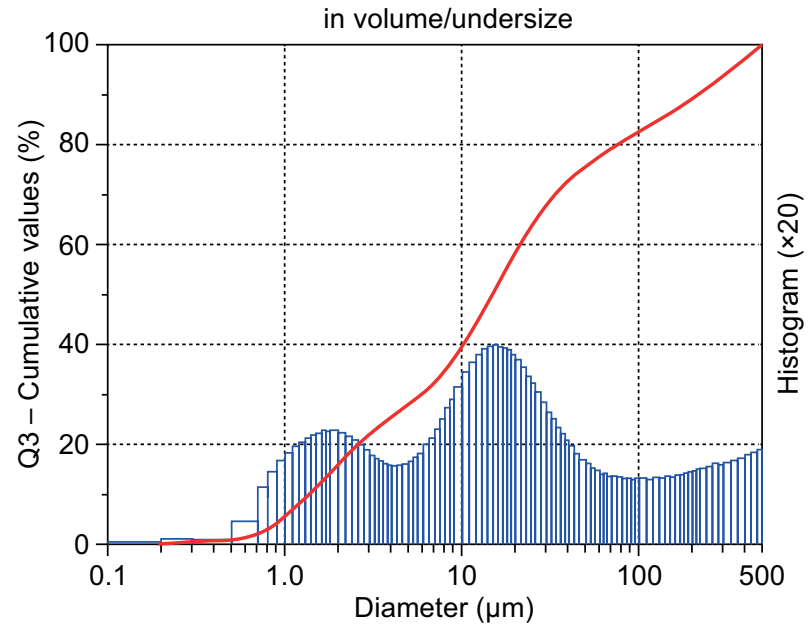

Figure 1. Mineral dust particle size distribution curves.

Table 4. Mixing proportion of concrete for $1 \mathrm{~m}^{3}$.

\begin{tabular}{lcccc}
\hline Amount of mineral dust \% & 0 & 2.5 & 5 & 7.5 \\
Slump value $(\mathrm{mm})$ & 170 & 165 & 160 & 140 \\
Cement $(\mathrm{kg})$ & 300 & 292.5 & 285 & 277.5 \\
Sand $0 / 4(\mathrm{~kg})$ & 900 & 900 & 900 & 900 \\
Gravel $4 / 16(\mathrm{~kg})$ & 1000 & 1000 & 1000 & 1000 \\
Chemical admixture $(\mathrm{kg})$ & 1.5 & 1.5 & 1.5 & 1.5 \\
Mineral dust $(\mathrm{kg})$ & 0 & 15 & 30 & 45 \\
Water $(\mathrm{kg})$ & 165 & 165 & 165 & 165 \\
\hline
\end{tabular}

The slump of concrete with the highest content of mineral dust was $30 \mathrm{~mm}$ lower compared to the control specimen because mineral dust reduces the slump of the mix. At higher contents of very fine aggregates in the mix a higher amount of superplasticiser or water is necessary to ensure the dispersion of fine particles in the $\operatorname{mix}[23]$.

EXO temperatures in concrete were measured using the methodology developed by Alcoa Company. A paste specimen of $1.5 \mathrm{~kg}$ weight was placed in a textolite moulder $(10 \times 10 \times 10)$. A type $\mathrm{T}$ thermocouple in a glass protection tube was placed in the specimen during curing. Temperature fluctuations were recorded in the $\mathrm{PC}$ on a continuous basis and it was measured according LST EN 12390-15 [24].

The slump of concrete mix was measured according to LST EN 12390-2:2019 [22], ultrasonic pulse velocity was measured according to LST EN 12504-4:2004 [25], water absorption rate was measured according to LST EN 13369:2018 [26], the density of hardened concrete was measured according to LST EN 12390-7:2019 [27], compressive strength was measured according to LST EN 12390-3:2019 [28].

Frost resistance factor $K_{F}$ was calculated basing on the assumption that concrete is frost resistant when the volume of closed pores is higher than the increased volume of freezing water in capillary pores.

Frost resistance factor $K_{F}$ is calculated from the equation:

$$
K_{F}=\frac{P_{u}}{0.09 P_{a}}
$$

where $P_{u}$ is closed porosity and $P_{a}$ is open porosity.

With the known value of frost resistance factor $K_{F}$, the resistance of concrete to freezing and thawing cycles can be predicted from the function of freeze-thaw resistance and frost resistance factor $K_{F}$ [29].

\section{RESEARCH RESULTS AND DISCUSSION}

In the mineral dust generated during the stone wool production process dominates dolomite, sylvite and halite minerals. Respectively dolomite waste contains $71.5 \%$, sylvite $-11.8 \%$ and halite $-4.8 \%$. Small amounts of quartz (4\%), muscovite $(2.9 \%)$ and kaolinite $(1.95 \%)$ were also detected by structural X-ray analysis (Figure 2). This test confirms previously shown stone wool production wastes chemical composition (Table 2). Although it shows that our specimen contains iron and the rise on the radiograph shows that also, crystalline phases could not be identified. This may be due to the fact that iron is in the form of fine crystals in the form of FeS or FeOOH.

Measurements of hydration heat released by concrete mixes with different content of mineral dust 
(Figure 3) revealed that at the same $\mathrm{W} / \mathrm{C}$ ratio the peak temperature of the exothermic hydration process was $29.27{ }^{\circ} \mathrm{C}$ in the mixes containing $5 \%$ of mineral dust and this value was higher than the hydration heat of the control mix $\left(28.03{ }^{\circ} \mathrm{C}\right)$. The highest exothermic temperature in concrete mixes containing $2.5 \%$ of mineral dust was $28.4{ }^{\circ} \mathrm{C}$ and it was also higher than the heat released by the control mix. In concrete mixes containing $7.5 \%$ of mineral dust the highest exothermic temperature of $27.27{ }^{\circ} \mathrm{C}$ was lower than in the control mix. Mineral dust actually had no effect on the speed of hydration heat release: the highest hydration heat was achieved after $16-17 \mathrm{~h}$. Mineral dust did not have any effect on the initial exothermic reaction temperature. Hydration heat release tests showed that the maximum temperature of the exothermic reaction is increased when up to $5 \%$ of cement in concrete mix is replaced by mineral dust. When more than $5 \%$ of mineral dust is used, the maximum temperature goes down.

Concrete density tests (Figure 4) showed that the density of concrete increased with the increase of mineral dust content in the cement mix up to $5 \%$. The density of concrete mix containing $5 \%$ of mineral dust was $1.16 \%$ higher than the density of the control specimen.

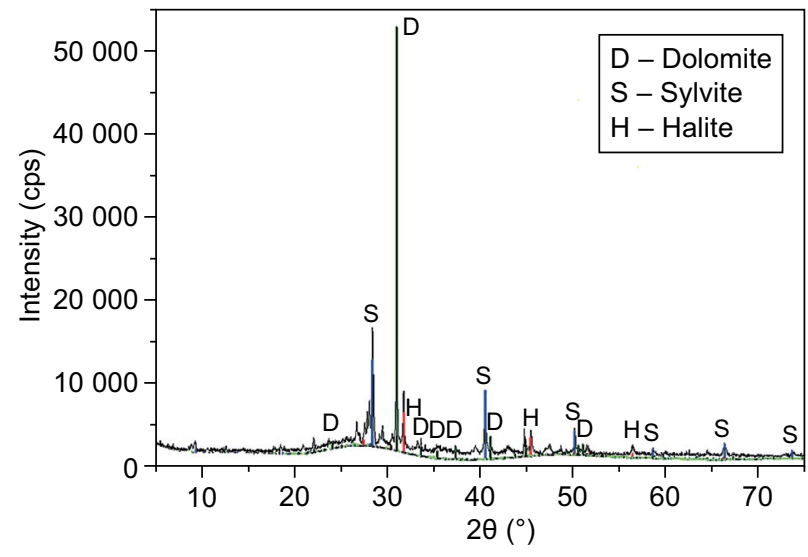

Figure 2. X-ray image of mineral dust.

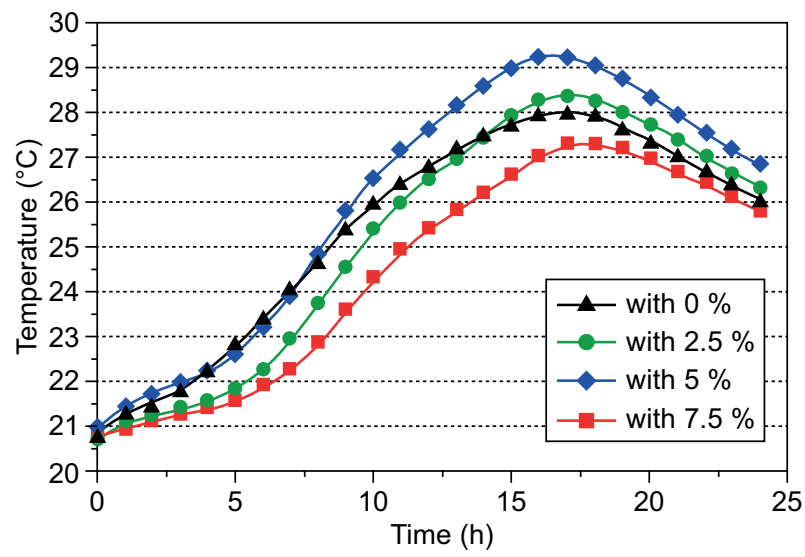

Figure 3. Relationship between the exothermic temperature and mineral dust content.
The density of concrete specimens containing more than $5 \%$ of mineral dust reduced after 28 days of curing. The density of concrete specimens containing $7.5 \%$ of mineral dust was $2394 \mathrm{~kg} \cdot \mathrm{m}^{-3}$. A denser structure formed during concrete curing because of mineral dust interaction with cement.

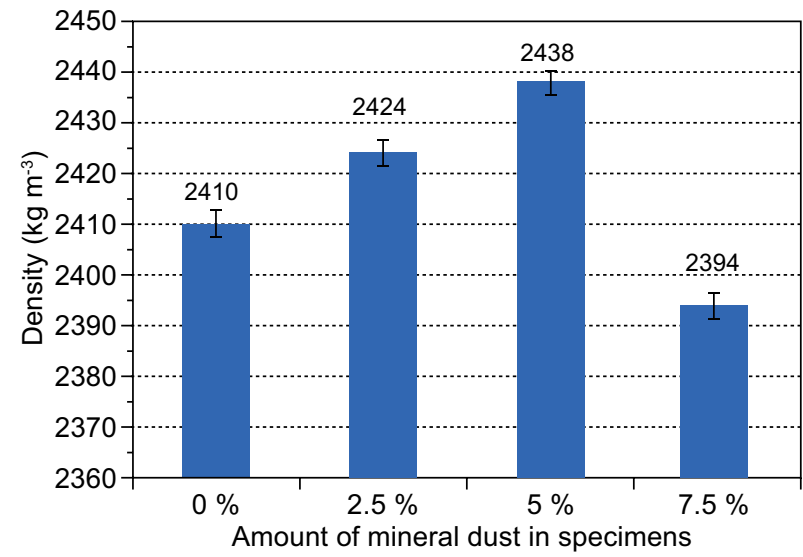

Figure 4. Relationship between density and mineral dust content.

Ultrasonic pulse velocity (UPV) tests (Figure 5) with concrete specimens after 28 days of curing showed that ultrasonic pulse velocity increased when up to $5 \%$ of cement was replaced with mineral dust. UPV in specimens containing $2.5 \%$ of mineral dust was $13 \mathrm{~m} \cdot \mathrm{s}^{-1}$ higher compared to the control specimen and in specimens containing $5 \%$ of mineral dust the UPV was $35 \mathrm{~m} \cdot \mathrm{s}^{-1}$ higher. UPV started decreasing when more than $5 \%$ of cement was replaced with mineral dust. In specimens containing $7.5 \%$ of mineral dust the UPV value was $35 \mathrm{~m} \cdot \mathrm{s}^{-1}$ lower than in the control specimen. UPV test results support the results of density tests in mineral dust modified concrete specimens. The highest UPV values were observed in the specimens where $5 \%$

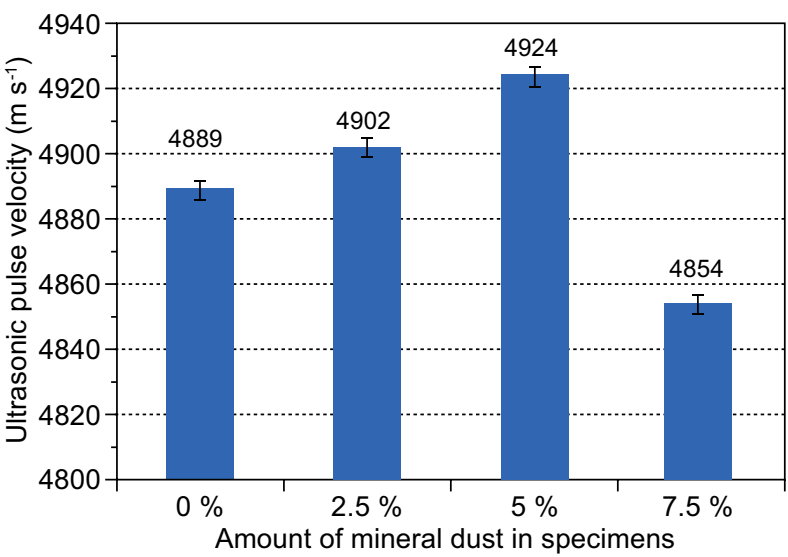

Figure 5. Relationship between ultrasonic pulse velocity and mineral dust content. 
of cement was replaced with mineral dust. Mineral dust participates in the formation of concrete structure. It was found that the activity of mineral dust was more intense when up to $5 \%$ of cement in concrete mix was replaced by mineral dust. When the content of mineral dust was higher than $5 \%$, the activity of this aggregate reduced.

The compressive strength of hardened concrete specimens was measured after 7 and 28 days of curing. The relationship between the compressive strength and mineral dust content is illustrated in Figure 6 . After 7 days of curing the lowest compressive strength value of $27.22 \mathrm{MPa}$ was found in the control specimen. In specimens containing $2.5 \%$ and $5 \%$ of mineral dust the com-pressive strength increased from 31.35 to $33.75 \mathrm{MPa}$ respectively. The highest compressive strength value was observed in the specimens modified with $5 \%$ of mineral dust. The same trend of the growth in compressive strength was observed after 28 days of curing. The highest compressive strength value was also observed in the specimens containing $5 \%$ of mineral dust. After 28 days of curing the compressive strength of the specimens containing $5 \%$ of mineral dust was $8.4 \%$ higher compared to the control specimen. However, the compressive strength started decreasing when more than $5 \%$ of cement is replaced with mineral dust. The compressive strength in specimens containing $7.5 \%$ of mineral dust was lower than in specimens where $5 \%$ of cement was replaced with mineral dust. The trend of the change in compressive strength values was the same as with density and ultrasonic pulse velocity values. The compressive strength increased with the increased mineral dust content up to $5 \%$ because the density and ultrasonic pulse velocity of concrete specimens increased.

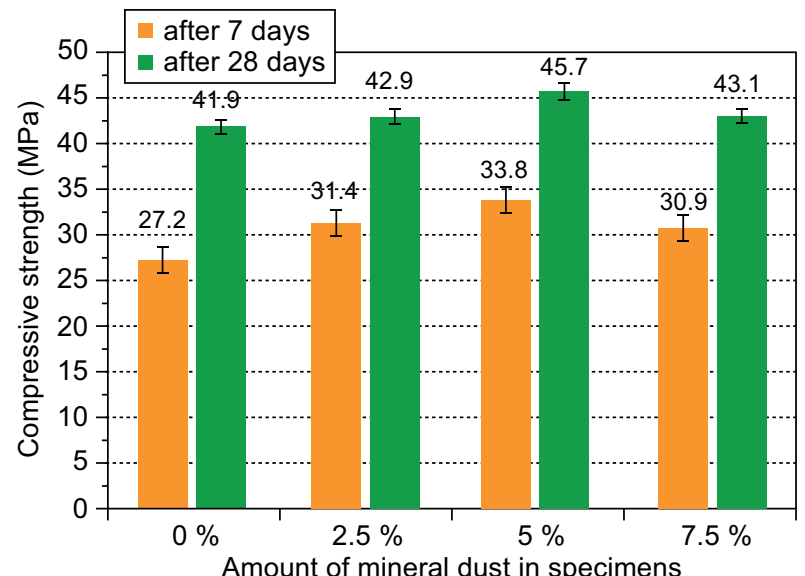

Figure 6. Relationship between the compressive strength after 7 and 28 days of curing and mineral dust content.

Water absorption (Figure 7) tests under normal conditions showed that water absorption decreased with the increase of mineral dust amount in the concrete mixes and subsequently the frost resistance of concrete increased. The lowest water absorption value was found in the specimens containing the biggest amount of mineral dust. In specimens containing $7.5 \%$ of mineral dust the water absorption was $6.49 \%$ lower compared to the control specimen. Water absorption decreases because mineral dust fills the voids of the aggregate material.

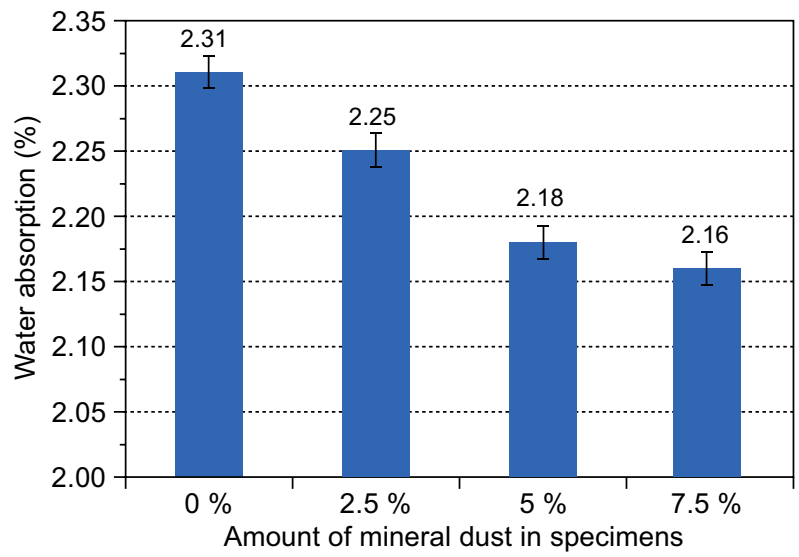

Figure 7. Relationship between water absorption and mineral dust content.

Open and closed porosity was measured in concrete specimens modified with different amounts of mineral dust. The obtained results are presented in the Figure 8. The results show that closed porosity increases with the increase of mineral dust in the concrete mix. The highest closed porosity, $1.79 \%$ higher than in the control specimen, was found in concrete mix where $7.5 \%$ of cement was replaced with mineral dust. The lowest closed porosity was found in the control specimen where cement was not replaced by mineral dust. Open porosity reduced with a higher amount of cement replaced by mineral dust. Open porosity was $5.17 \%$ in concrete mixes where $7.5 \%$ of cement was replaced by mineral dust. The highest open porosity of $5.57 \%$ was observed in control specimens.

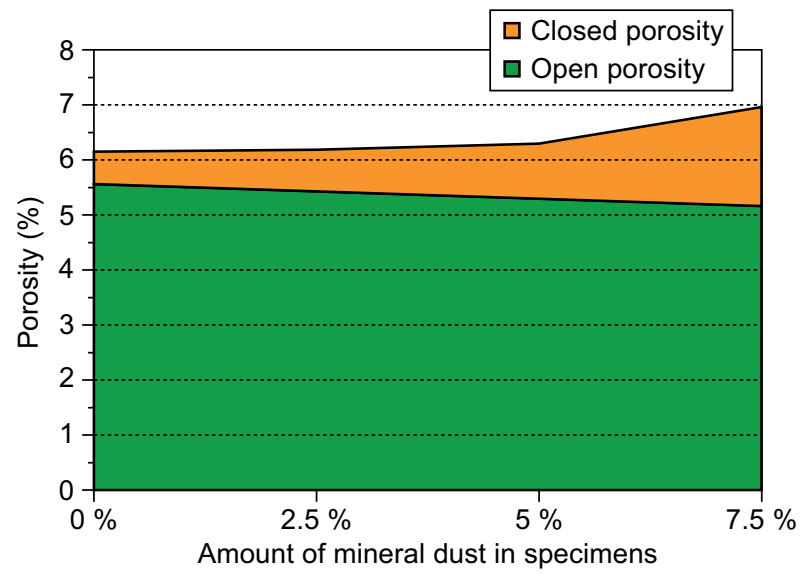

Figure 8. Relationship between porosity and mineral dust content. 
The predicted resistance to freezing and thawing cycles is presented in Figure 9. Frost resistance tests revealed that concrete specimens with a higher content of mineral dust had better frost resistance and durability properties. The highest frost resistance value was observed in concrete specimens where $7.5 \%$ of cement was replaced by mineral dust and the lowest value was obtained in the control specimen that was not modified by mineral dust. The highest and the lowest frost resistance values were 679 and 219 cycles respectively. Frost resistance depends primarily on the structure of the material. Specimens modified by mineral dust had fewer open pores and more closed pores. Subsequently the hardened concrete absorbed less water, withstood more freezing and thawing cycles and thus was more durable than the control specimens.

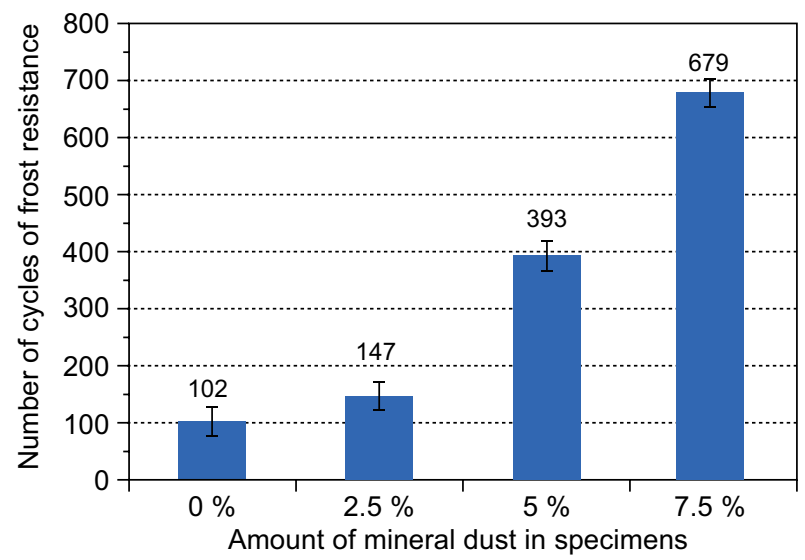

Figure 9. Relationship between resistance to freezing and thawing cycles and mineral dust content.

The testing results showed that mineral dust had improved certain properties of concretes. Concrete mixes where up to $5 \%$ of cement was replaced by mineral dust had better hydration characteristics, higher density of hardened concrete, higher ultrasonic pulse velocity and compressive strength values. However, the positive effect reduced when the content of mineral dust exceeded $5 \%$.

The tests revealed that concrete containing mineral dust absorbed less water because the specimens had fewer open pores and therefore had better frost resistance. A higher content of mineral dust in concrete mix reduces water absorption rate, open and close porosity, increases the resistance of concrete to cyclic freezing and thawing and thus improves the durability of concrete.

\section{CONCLUSIONS}

It was found that the highest temperature of exothermic reaction $\left(29.27{ }^{\circ} \mathrm{C}\right)$ in concrete mixes modified with up to $5 \%$ of stone wool production residue (mineral dust) was higher compared to that of control specimens $\left(28.03^{\circ} \mathrm{C}\right)$, whereas the time required to reach the maximum heat of hydration was not influenced by the addition of mineral dust.

The research showed that concrete specimens modified with $5 \%$ of mineral dust had the highest density. Ultrasonic pulse velocity measured after 28 days of curing was the highest $\left(4924 \mathrm{~m} \cdot \mathrm{s}^{-1}\right)$ in concrete specimens containing $5 \%$ of mineral dust.

Mineral dust added to the concrete mix at $5 \%$ by weight of cement increases the compressive strength of hardened concrete after 7 and 28 days of curing. After 28 days of curing the highest compressive strength of $45.69 \mathrm{MPa}$ was achieved in hardened concrete specimens containing $5 \%$ of mineral dust. The compressive strength of these specimens was $8.4 \%$ higher than the strength of the control specimens. However, in specimens containing more than $5 \%$ of mineral dust the compressive strength decreased to $42.12 \mathrm{MPa}$.

The tests revealed that concrete specimens containing $7.5 \%$ of mineral dust absorbed less water due to a lower volume of open pores and therefore the specimens had better frost resistance. A higher content of mineral dust in concrete mix reduces water absorption rate, open and close porosity, increases the resistance of concrete to cyclic freezing and thawing and thus improves the durability of concrete.

The results of the tests lead to the conclusions that small amounts of stone wool production residue (mineral dust) can be added to concrete mixes in order to reduce the amount of cement used and to utilise waste from stone wool manufacture. Stone wool production residue can be applied to modify concrete resulting in structural concrete with better durability and frost resistance characteristics.

\section{REFERENCES}

1. Najim K.B., Mahmod Z.S., Atea A.M. (2014): Experimental investigation on using cement kiln dust (CKD) as a cement replacement material in producing modified cement mortar. Construction and Building Materials, 55, 5-12. doi: 10.1016/j.conbuildmat.2014.01.015

2. Scrivener K., Kirkpatrick R. (2005). Innovation in use and research on cementations materials. In: $12^{\text {th }}$ international congress of chemistry of cement. Montreal, Canada.

3. Mehta PK. (2004). High-performance, high-volume fly ash concrete for sustainable development. In: Proceedings of international workshop on sustainable development and concrete technology. pp 3-14.

4. Kogler K. (2007). Life Focus/Life and waste recycling: Innovative waste management options in Europe. Office for Official Publications of the European Communities. Luxembourg, p. 56.

5. Cheng A., Lin W., Huang R. (2010): Application of rock wool waste in cement-based composites. Materials and Design, 32, 636-642. doi: 10.1016/j.matdes.2010.08.014

6. Wei M.-S., Huang K.-H. (2001): Recycling and reuse of industrial wastes in Taiwan. Waste Management, 21, 93-97. doi: 10.1016/S0956-053X(00)00073-8 
7. Chen C.H., Huang R., Wu J.K., Yang C.C. (2006): Waste E-glass particles used in cementitious mixtures. Cement and Concrete Research, 36, 449-456. doi: 10.1016/j.cemconres. 2005.12.010

8. Wu H.-C., Sun P. (2007): New building materials from fly ash-based lightweight inorganic polymer. Construction and Building Materials, 21(1), 211-217. doi: 10.1016/j.conbuildmat.2005.06.052

9. Sun P., Wu H.-C. (2008): Transition from brittle to ductile behavior of fly ash using PVA fibers. Cement and Concrete Composites, 30, 29-36. doi: 10.1016/j.cemconcomp.2007. 05.008

10. Kizinievič O., Balkevičius V., Pranckevičienė J., Kizinievič V. (2014): Investigation of the usage of centrifuging waste of mineral wool melt (CMWW), contaminated with phenol and formaldehyde, in manufacturing of ceramic products. Waste Management, 34, 1488-1494. doi: 10.1016/j.wasman.2014.01.010

11. Stonys R., Kuznetsov D., Krasnikovs A., Skamat J., Baltakys K., Antonovič V., Černašejus O. (2015): Reuse of ultrafine mineral wool production waste in the manufacture of refractory concrete. Journal of Environmental Management, 176, 149-156. doi: 10.1016/j.jenvman.2016.03.045

12. Paroc-WIM. Waste injection into the stone wool melting furnace. Report of Environment LIFE Project LIFE02 ENV/FIN/000328, available at http://ec.europa.eu.

13. Jackson R. (1998). Briquetting enables efficient recycling of rock mineral wool process residues environmental technology best practise programme. Owens-Corning - Building Materials Europe.

14. Kubiliute R., Kaminskas R., Kazlauskaitè A. (2018): Mineral wool production waste as an additive for Portland cement. Cement and Concrete Composites, 88, 130-138. doi: 10.1016/j.cemconcomp.2018.02.003

15. Hattori T., Matsuda M., Miyake M. (2006): Resource Recovery of Cupola Dust: Study on Sorptive Property and Mechanism for Hydrogen Sulfide. Journal of Materials Science, 41, 3701-3706. doi: 10.1007/s10853-006-6223-6

16. Michihiro M. (2007): Resource Recovery of Inorganic Solid Waste for Reduction of Environmental Load. Journal of the Ceramic Society of Japan, 115, 1-8. doi: 10.2109/ jcersj.115.1

17. Žvironaite J., Antonovič V., Pundienė I., Balkevičius V. (2011): Investigation of peculiarities in the hardening process of portland cements with active additives out of waste. Materials science (Medžiagotyra), 17, 1. doi: 10.5755/ j01. ms.17.1.254

18. Erofeeva V.T., Rodina A.I., Bochkinb V.S., Yakunina V.V., Ermakova A.A. (2020): Lightweight geopolymers made of mineral wool production waste. Magazine of Civil Engineering, 93(1), 3-12. doi: 10.18720/MCE.93.1

19. Erofeev V.T., Rodin A.I., Yakunin V.V., Bogatov A.D., Bochkin V.S., Chegodajkin A.M. (2018): Alkali-activated slag binders from rock-wool production wastes. Magazine of Civil Engineering, 6, 219-227. doi: 10.18720/MCE.82.20

20. LST EN 197-1:2011/P:2013. Cement-Part 1: Composition, specifications and conformity criteria for common cements.

21. LST EN 12620:2003+A1:2008. Aggregates for concrete.

22. LST EN 12390-2 (2019). Testing hardened concrete - Part 2: Making and curing specimens for strength tests.

23. Li L.G., Zheng J.Y., Ng P.-L., Kwan A.K.H. (2021): Synergistic cementing efficiencies of nano-silica and micro-silica in carbonation resistance and sorptivity of concrete. Journal of Building Engineering, 33, 101862. doi: 10.1016/j.jobe. 2020.101862

24. LST EN 12390-15 (2019). Testing hardened concrete - Part 15: Adiabatic method for the determination of heat released by concrete during its hardening process.

25. LST EN 12504-4 (2004). Testing concrete - Part 4: Determination of ultrasonic pulse velocity.

26. LST EN 13369 (2018). Common rules for precast concrete products.

27. LST EN 12390-7 (2019). Testing hardened concrete - Part 7: Density of hardened concrete.

28. LST EN 12390-3 (2019). Testing hardened concrete - Part 3: Compressive strength of test specimens.

29. Skripkiūnas G. (2007). Statybiniu konglomeratu struktūra ir savybes: vadovelis. Kaunas: Vitae Litera, p. 334. 